\title{
ANALISIS KESUBURAN TANAH DAN RESIDU PEMUPUKAN PADA TANAH DENGAN MENGGUNAKAN METODE KEMAGNETAN BATUAN
}

\author{
R. ALMIATI ${ }^{1 *}$ DAN E. AGUSTIN ${ }^{2}$ \\ ${ }^{1}$ Program Studi Teknik Geofisika, Jurusan Sains, Institut Teknologi Sumatera \\ Jalan Terusan Ryacudu, Way Hui, Jati Agung, 35365, Lampung Selatan, Lampung \\ ${ }^{2}$ Departemen Geofisika, FMIPA, Universitas Padjadjaran \\ Jl. Raya Bandung-Sumedang Km.21 Jatinangor 45363, Sumedang, Jawa Barat \\ *email : restu.almiati@tg.itera.ac.id
}

\begin{abstract}
Abstrak. Unsur yang selalu ada dalam tanah adalah unsur besi (Fe) yang merupakan salah satu unsur magnetik. Ukuran tanah tersebut memiliki unsur magnetik ditunjukkan dengan nilai suseptibilitas magnetik. Suseptibilitas magnetik merupakan salah satu parameter yang digunakan dalam metode kemagnetan batuan. Dalam penelitian ini akan dilihat perubahan nilai suseptibilitas magnetik dan variasi sifat mineral magnetik dalam tanah (XRD dan SEM-EDX) serta parameter lainnya meliputi pH, konduktivitas dan struktur tanah. Hal ini dapat memberikan informasi mengenai kesuburan tanah dikhususkan tanah lahan sawah yang dianggap sudah terdegradasi, jika dibandingkan dengan tanah hutan yang dianggap subur dan alami. Berdasarkan penelitian yang telah dilakukan dapat dikatakan bahwa tanah hutan masih subur dan alami karena didominasi mineral magnetik magnetite $\left(\mathrm{Fe}_{3} \mathrm{O}_{4}\right)$, $\mathrm{pH}$ netral, konduktivitas cukup besar dan berstruktur remah. Sedangkan tanah dari sawah dapat dikatakan sudah terdegradasi karena didominasi mineral magnetik pyrhotite $\left(\mathrm{Fe}_{7} \mathrm{~S}_{8}\right)$ yang diduga dari pemupukan dan titanohaematite $\left(\mathrm{Fe}_{2} \mathrm{O}_{3}-\mathrm{FeTiO}_{3}\right)$ yang diduga menyebabkan tanah menjadi sangat basa. Selain itu $\mathrm{pH}$ tanah sawah netral cenderung basa, konduktivitas kecil dan struktur tanahnya remah. Adanya unsur $\mathrm{Na}$ dan $\mathrm{Ca}$ pada tanah sawah diduga merupakan sisa dari pemupukan.
\end{abstract}

Kata kunci : kemagnetan batuan, suseptibilitas magnetik, mineral magnetik

Abstract. Soil is composed of several elements. The element that is always present in the soil is iron $(\mathrm{Fe})$, which is one of the magnetic elements. How much land has magnetic properties shown by magnetic susceptibility. Magnetic susceptibility is one of the parameters used in rock magnetism method. In this study, we will see the change in value of magnetic susceptibility and variations in the nature of magnetic minerals of soil as well as other parameters include $\mathrm{pH}$, conductivity and soil structure. It can provide information on soil fertility of land devoted wetland that considered degraded, compared to forest land that considered fertile and natural. From this study, it can be said that the land from forest was fertile and natural as dominated by the magnetic mineral magnetite $\left(\mathrm{Fe}_{3} \mathrm{O}_{4}\right)$, neutral $\mathrm{pH}$, conductivity is quite large and structured crumb. While the soil of the fields can be said have been degraded due to magnetic minerals dominated pyrhotite (Fe7S8) that suspected of fertilization and titanohaematite $\left(\mathrm{Fe}_{2} \mathrm{O}_{3}-\mathrm{FeTiO}_{3}\right)$ that allegedly caused the ground becomes very alkaline. Besides, paddy soil $\mathrm{pH}$ tends neutral alkaline, small conductivity and soil crumb structure. The existence of the elements $\mathrm{Na}$ and $\mathrm{Ca}$ on paddy soil believed to be the remainder of fertilization.

Keywords : rock magnetism, magnetic susceptibility, magnetic mineral 


\section{Pendahuluan}

Keadaan tanah sangat dinamis, beberapa hal yang menyebabkan kesuburan tanah berkurang yaitu usaha pertanian yang menyebabkan hilangnya beberapa unsur hara pada tanah akibat proses erosi, pencucian, pembawaan oleh hasil pertanian dan pemupukan yang tidak tepat. Kemungkinan terjadi degradasi tanah (penurunan tingkat produktivitas tanah) yang dikhususkan tanah lahan sawah diakibatkan oleh kejenuhan pupuk tertentu.

Pada penelitian ini akan, penulis mengidentifikasi kondisi tanah beberapa daerah di Bandung menggunakan metode kemagnetan batuan. Daerah Bandung merupakan daerah yang subur, hal ini diakibatkan oleh adanya aktifitas gunung api, terutama daerah Bandung Utara. Sampel tanah dari lahan sawah yang sudah terdegradasi dibandingkan dengan sampel tanah dari hutan yang dianggap subur dan alami. Tanah subur yaitu tanah yang kesuburan kimia tanahnya baik seperti kemasaman tanah ( $\mathrm{pH}$ tanah) netral, kandungan unsur-unsur hara tanah tersedia baik (cukup) untuk pertumbuhan tanaman dan sebagainya. Kesuburan fisik baik seperti tekstur lempung, konsistensi gembur, struktur remah dan porositas baik. Kesuburan biologi tanah baik (aktivitas jasad hidup tanah cukup tinggi) dan tidak terdapat pembataspembatas tertentu bagi pertumbuhan tanaman tertentu. Tanah yang alami ditunjukkan dengan agregat tanah yang masih tajam. Hasil pengukuran akan memperoleh beberapa parameter seperti jenis mineral tanah, kandungan unsur hara mikro $\mathrm{Fe}$ dan data pendukung lainnya ( $\mathrm{pH}$, konduktivitas dan struktur tanah). Persentase kandungan suatu unsur diharapkan dapat menunjukkan kejenuhan pupuk tertentu pada tanah.

Kemagnetan batuan sering digunakan dalam kajian lingkungan, menggunakan perubahan dan variasi sifat mineral magnetik dalam tanah, debu, atau sedimen sebagai indikator dari proses yang terjadi di lingkungan. Pada penelitian ini, kesuburan tanah akan diketahui dari sifat kemagnetan yang dilihat dari karakter nilai suseptibilitasnya. Untuk mengetahui jenis mineral dan persentase kandungan besinya $(\% \mathrm{Fe})$, dilakukan pengukuran nilai suseptibiliats magnetik, selain itu $\mathrm{pH}$ dan konduktivitas tanah diukur sebagai pendukung pendugaan kesuburan tanah lahan pertanian di daerah Bandung.

Pada tahun 1970 pertama kali ilmuwan menggunakan pengukuran suseptibilitas magnet untuk menggambarkan dan mengklasifikasi material yang ada di lingkungan. Magnetisasi di alam yang terdapat pada batuan, tanah maupun sedimen dapat memberikan informasi tentang jejak perubahan lingkungan yang terjadi (Dearing, 1999).

$$
\chi=\frac{\vec{M}}{\vec{H}}
$$

Mineral magnetik batuan di alam terdiri dari keluarga Oksida Besi - Titanium (FeTiO), Hidroksida Besi, serta Sulfida Besi. Selain magnetite $\left(\mathrm{Fe}_{3} \mathrm{O}_{4}\right)$, Oksida Besi mencakup mineral Ulvospinel $\left(\mathrm{Fe}_{3} \mathrm{TiO}_{4}\right)$, Hematite $\left(\mathrm{Fe}_{2} \mathrm{O}_{3}\right)$, Heminite $\left(\mathrm{FeTiO}_{4}\right)$ dan maghemite $\left(\mathrm{Fe}_{2} \mathrm{O}_{3}\right)$. Di alam sebagian besar mineral magnetik yang ada merupakan Oksida Besi Titanium dalam bentuk deret Titanomagnetite dan deret Titanohaematite juga sebagian dalam bentuk hidroksida besi seperti goethite. 
Deret Titanomagnetite

Komposisi antara anggota ujung magnetite $\left(\mathrm{Fe}_{3} \mathrm{O}_{4}\right)$ dan Ulvosvinel $\left(\mathrm{Fe}_{2} \mathrm{TiO}_{4}\right)$. Rumus kimia secara umum adalah $\left(\mathrm{Fe}_{3-\mathrm{x}} \mathrm{Ti}_{\mathrm{x}} \mathrm{O}_{4}\right)$ dengan $\mathrm{x}$ berkisar dari 0.0 untuk magnetite sampai 1.0 untuk Ulvospinel.

\section{Deret Titanohaematite}

Dua anggota terakhir dari deret ini adalah Haematite $\left(\mathrm{Fe}_{2} \mathrm{O}_{3}\right)$ dan Ilmenite $\left(\mathrm{FeTiO}_{3}\right)$. Titanohaematite pada umumnya merupakan mineral yang tidak tembus cahaya. Rumus umumnya adalah $\mathrm{Fe}_{2-\mathrm{x}} \mathrm{Ti}_{\mathrm{x}} \mathrm{O}_{3}$ dengan $\mathrm{x}$ berkisar dari 0.0 untuk haematite sampai 1.0 untuk Ilmenite (Butler, 1992). Komposisi dari Fe-Ti oksida ditunjukkan oleh ternary-diagram $\mathrm{TiO}_{2}-\mathrm{FeO}-\mathrm{Fe}_{2} \mathrm{O}_{3}$ pada Gambar 1 berikut:

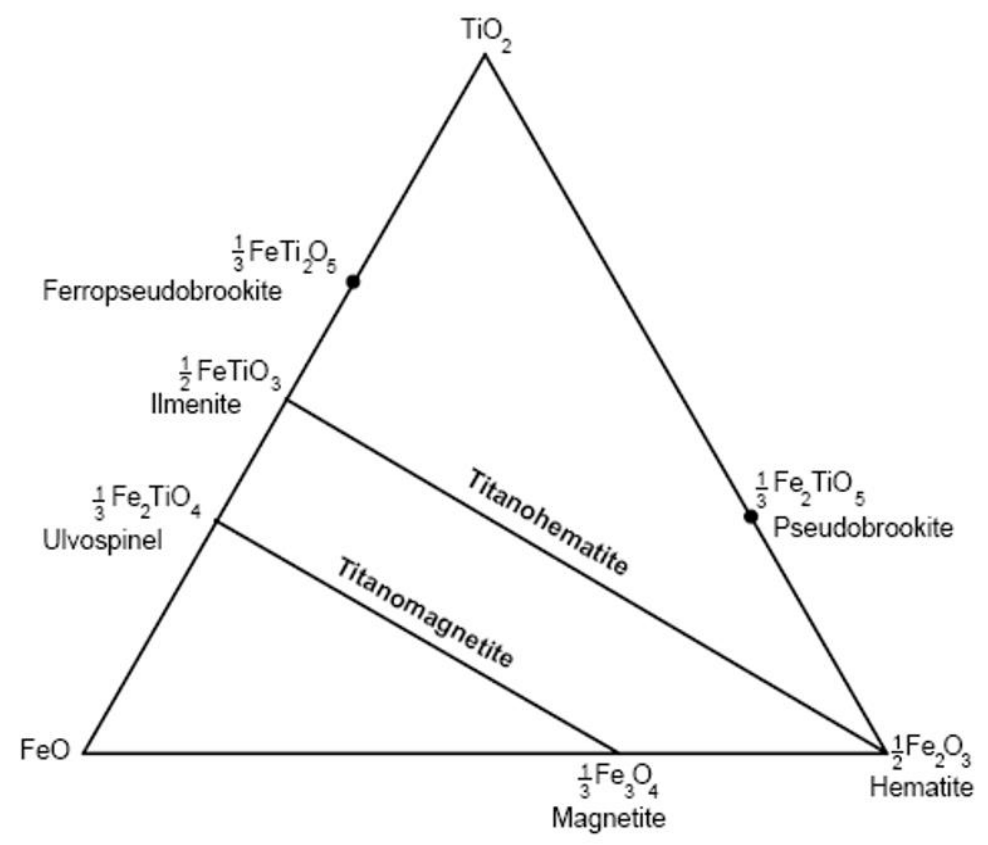

Gambar 1. Diagram Ternary Komposisi Fe-Ti-O

\section{Metode Penelitian}

Alur metodologi penelitian dapat dilihat pada gambar 1, tahap akuisisi data, peneliti memilih 5 lokasi sawah di Bandung berarah utara-selatan berdasarkan jenis batuan yang cukup beragam dilihat dari peta geologi yang dianggap mewakili kota Bandung. Lokasi tersebut antara lain Cisaranten, Cigiringsing, Sukapura, Baleendah dan Hutan Djuanda Dago. Peneliti kemudian menamai sampel dan mengukur $\mathrm{pH}$, konduktivitas dan suseptibilitas magnetiknya. Jenis mineral tanah diidentifikasi menggunakan XRD (X-Ray Difraction) sedangkan persentase unsur terkandung diidentifikasi menggunakan SEM-EDX (Scanning Electron Microscope Energy Dispersive X-Ray). 


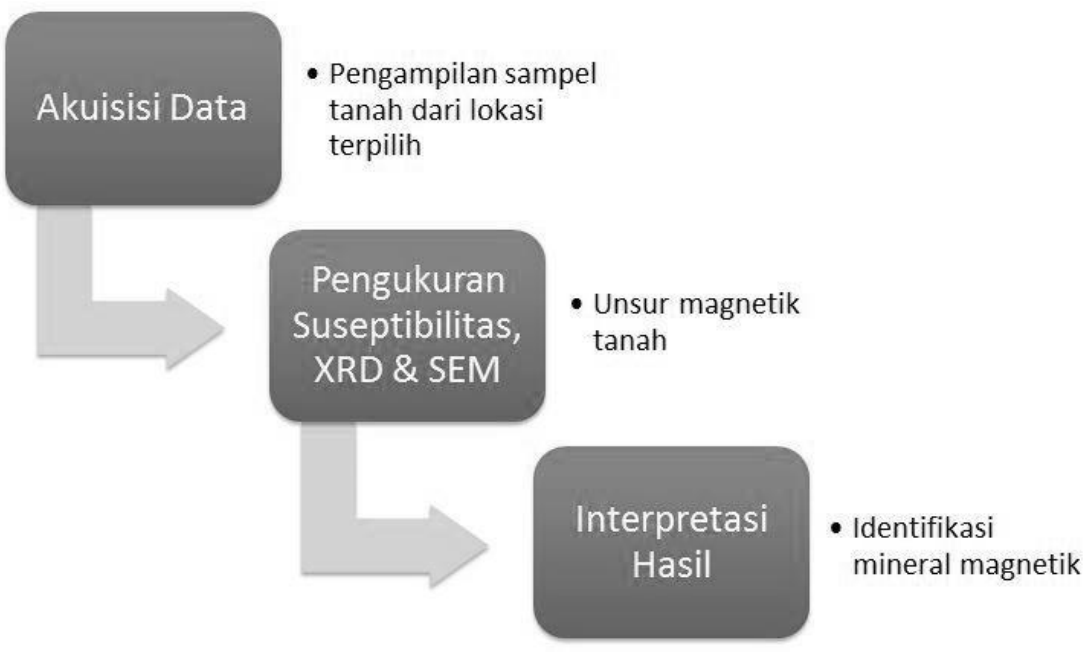

Gambar 2. Diagram Alir Penelitian

\section{Hasil dan Pembahasan}

Hasil pengukuran nilai suseptibilitas, XRD dan SEM-EDX berupa gambar logam berat, presentase unsur dan jenis mineral digunakan untuk melihat pergeseran perubahan mineral magnetik pada tanah yang berasal dari 5 (lima) lokasi (Hutan Djuanda, Cisaranten, Cigiringsing, Sukapura dan Baleendah), dengan hasil sebagai berikut.

\section{Hutan Djuanda}

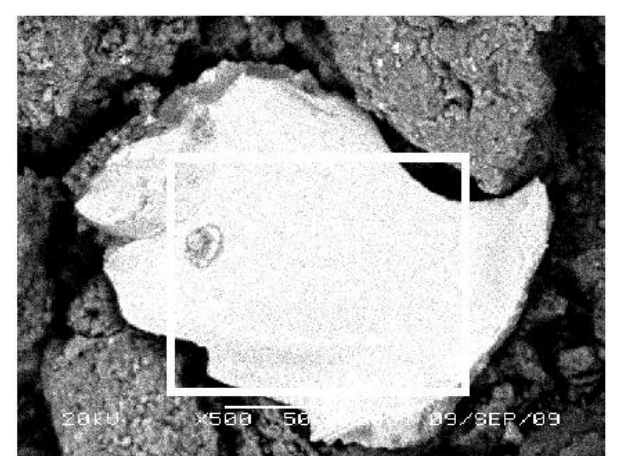

Gambar 3. Hasil SEM-EDX logam berat sampel tanah di Hutan Djuanda

Tabel 1. Hasil SEM-EDX logam berat, XRD dan suseptibilitas sampel tanah di Hutan Djuanda

\begin{tabular}{lccc}
\hline \multicolumn{2}{c}{ Hasil SEM-EDX } & Hasil XRD & Hasil Suseptibilitas \\
\hline element & Mass $(\%)$ & Albite & Magnetite $\left(\mathrm{Fe}_{3} \mathrm{O}_{4}\right)$ \\
$\mathrm{O}($ Oxide $)$ & 26.61 & $\left.(\mathrm{Na}, \mathrm{Ca}) \mathrm{Al}(\mathrm{Si}, \mathrm{Al}) 3 \mathrm{O}_{8}\right)$ & \\
$\mathrm{Mg}$ (magnesium) & 2.18 & $\mathrm{Maghemite}$ & \\
$\mathrm{Al}($ Alumunium) & 4.19 & $\left(\mathrm{Fe}_{2} \mathrm{O}_{3}\right)$ & \\
$\mathrm{Ti}$ (titanium) & 5.87 & $\mathrm{Kaolinite}$ & \\
$\mathrm{Fe}$ (ferrum) & 61.14 & $\left(\mathrm{Al}_{2} \mathrm{Si}_{2} \mathrm{O}_{5}(\mathrm{OH})_{4}\right)$ & \\
& & Quartz & \\
& & $\left(\mathrm{SiO}_{2}\right)$ & \\
\hline
\end{tabular}


Unsur Fe dan Al pada hasil SEM-EDX sesuai dengan hasil XRD, yaitu adanya mineral albite, maghemite dan kaolinite. Hasil suseptibilitas magnetik mengidentifikasi adanya mineral magnetik magnetite yang memiliki nilai suseptibilitas paling besar dan menunjukkan bahwa kandungan unsur $\mathrm{Fe}$ di tanah hutan itu besar. Pergeseran perubahan mineral magnetik bisa dilihat dari persentase unsur Fe, Ti dan O hasil SEM-EDX. Sehingga diperoleh formula:

$\mathrm{Fe}_{2.903991} \mathrm{Ti}_{0.096009} \mathrm{O}_{4}$

Formula tersebut termasuk mineral magnetite $\mathrm{Fe}_{3-\mathrm{x}} \mathrm{Ti}_{\mathrm{x}} \mathrm{O}_{4}$ dengan besar $\mathrm{x}$ mendekati nol dan Fe mendekati 3.

\section{Cisaranten}

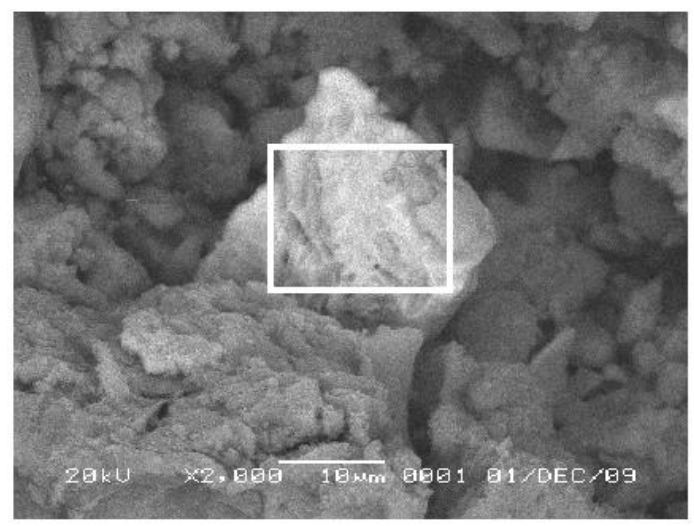

Gambar 4. Hasil SEM-EDX logam berat sampel tanah di Cisaranten

Tabel 2. Hasil SEM-EDX logam berat, XRD dan suseptibilitas sampel tanah di Cisaranten

\begin{tabular}{llcc}
\hline \multicolumn{2}{c}{ Hasil SEM-EDX } & Hasil XRD & Hasil Suseptibilitas \\
\hline element & Mass $(\%)$ & $\mathrm{Kaolinite}_{2}$ & Pyrhotite $\left(\mathrm{Fe}_{7} \mathrm{~S}_{8}\right)$ \\
$\mathrm{O}$ (oxide) & 14.66 & $\left(\mathrm{Al}_{2} \mathrm{Si}_{2} \mathrm{O}_{5}(\mathrm{OH})_{4}\right)$ & \\
$\mathrm{Mg}$ (magnesium) & 1.12 & Quartz & \\
$\mathrm{Al}($ alumunium) & 3.3 & $\left(\mathrm{SiO}_{2}\right)$ & \\
$\mathrm{Ti}$ (titanium) & 9.11 & $\mathrm{Heulandite}$ & \\
$\mathrm{Fe}$ (ferrum) & 64.04 & $\left(\mathrm{CaAl}_{2} \mathrm{Si}_{7} \mathrm{O}_{18} 17.5 \mathrm{H}_{2} \mathrm{O}\right)$ & \\
$\mathrm{Si}$ (silika) & 3.31 & $\mathrm{Calcite}$ & \\
$\mathrm{C}($ karbon) & 4.45 & $\left(\mathrm{CaCO}_{3}\right)$ & \\
\hline
\end{tabular}

Unsur Fe dari SEM-EDX bersesuaian dengan hasil suseptibilitas magnetik, sedangkan unsur $\mathrm{Al}$ dan $\mathrm{C}$ bersesuaian dengan hasil XRD yang ditunjukkan dengan adanya mineral calcite dan kaolinite. Pergeseran perubahan mineral magnetiknya :

$\mathrm{Fe}_{1.8585} \mathrm{Ti}_{0.1414} \mathrm{O}_{3}$

Dari formula di atas, jenis mineral perubahannya termasuk kepada mineral hematite Fe2-xTixO3 dengan besar x mendekati nol dan Fe mendekati 2. 


\section{Cigiringsing}

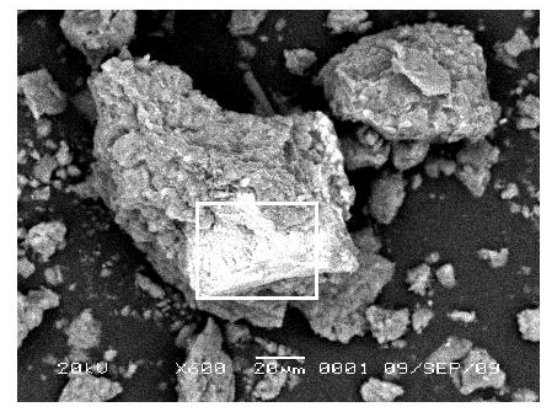

Gambar 5. Hasil SEM-EDX logam berat sampel tanah di Cigiringsing

Tabel 3. Hasil SEM-EDX logam berat, XRD dan suseptibilitas sampel tanah di Cigiringsing

\begin{tabular}{llcc}
\hline \multicolumn{2}{c}{ Hasil SEM-EDX } & Hasil XRD & Hasil Suseptibilitas \\
\hline element & Mass $(\%)$ & Cristobalite & Maghemite $\left(\mathrm{Fe}_{2} \mathrm{O}_{3}\right)$ \\
$\mathrm{O}$ (oxide) & 26.15 & $\left(\mathrm{SiO}_{2}\right)$ & \\
$\mathrm{Al}($ alumunium) & 2.76 & $\mathrm{Monmorillonite}$ & \\
$\mathrm{Si}$ (silika) & 1.92 & $\left(\mathrm{NaO}^{2} \mathrm{Al}_{4} \mathrm{Si}_{6} \mathrm{O}_{15}(\mathrm{OH})_{6} 14 \mathrm{H}\right.$ & \\
& & & \\
$\mathrm{Ti}$ (titanium) & 4.61 & Quartz & \\
$\mathrm{Fe}$ (ferrum) & 62.74 & $\left(\mathrm{SiO}_{2}\right)$ & \\
$\mathrm{Cu}$ (cuprum) & 1.82 & $\mathrm{Microsommite}$ & \\
& & $(\mathrm{Na}, \mathrm{Ca}, \mathrm{K})_{8}(\mathrm{Si}, \mathrm{Al})_{12} \mathrm{O}_{24}$ & \\
\hline
\end{tabular}

Unsur Fe hasil SEM-EDX bersesuaian dengan hasil suseptibilitas magnetik, sedangkan unsur Al sesuai dengan hasil XRD yang ditunjukkan dengan adanya mineral microsomite dan montmorilonit. Pergeseran perubahan mineral magnetik bisa dilihat dari persentase unsur Fe, Ti dan O hasil SEM-EDX dengan formula :

$$
\mathrm{Fe}_{2.926522} \mathrm{Ti}_{0.073478} \mathrm{O}_{4}
$$

Formula tersebut termasuk mineral magnetite $\mathrm{Fe}_{3-\mathrm{x}} \mathrm{Ti}_{\mathrm{x}} \mathrm{O}_{4}$ dengan besar x mendekati nol tetapi nilainya lebih kecil dari nilai x sampel tanah hutan dan Fe mendekati 3 tetapi nilainya lebih besar dari sampel tanah hutan.

\section{Sukapura}

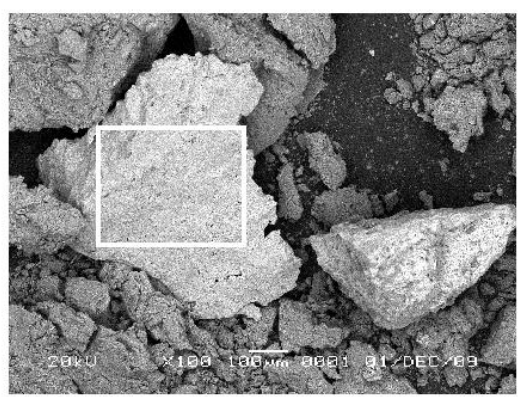

Gambar 6. Hasil SEM-EDX logam berat sampel tanah di Sukapura 
Tabel 4. Hasil SEM-EDX logam berat, hasil XRD dan suseptibilitas sampel tanah di Sukapura

\begin{tabular}{llcc}
\hline \multicolumn{1}{c}{ Hasil SEM-EDX } & Hasil XRD & Hasil Suseptibilitas \\
\hline element & Mass $(\%)$ & Paragonite & Pyrhotite $\left(\mathrm{Fe}_{7} \mathrm{~S}_{8}\right)$ \\
$\mathrm{O}$ (Oxide) & 16.79 & $\left(\mathrm{NaAl}_{2}\left(\mathrm{AlSi}_{3}\right) \mathrm{O}_{10}(\mathrm{OH})_{2}\right.$ & \\
$\mathrm{Al}$ & 6.07 & $\mathrm{Quartz}$ & \\
$\mathrm{Si}$ & 7.86 & $\left(\mathrm{SiO}_{2}\right)$ & \\
$\mathrm{Fe}$ (ferrum) & 69.29 & $\mathrm{Cristobalite}$ & \\
& & $\left(\mathrm{SiO}_{2}\right)$ & \\
& & $\mathrm{Kaolinte}$ & \\
& & $\left(\mathrm{Al}_{2} \mathrm{Si}_{2} \mathrm{O}_{5}(\mathrm{OH})_{4}\right)$ & \\
\hline
\end{tabular}

Unsur Fe bersesuaian dengan hasil suseptibilitas magnetik yang menunjukkan nilai suseptibilitas mineral magnetik pyrhotite $\left(\mathrm{Fe}_{7} \mathrm{~S}_{8}\right)$, sedangkan unsur Al bersesuaian dengan hasil XRD, yaitu adanya mineral paragonite dan kaolinite. Pergeseran perubahan mineral magnetik bisa dilihat dari persentase unsur Fe dan O hasil SEMEDX.

$$
\mathrm{Fe}_{4.12} \mathrm{O}
$$

\section{Baleendah}

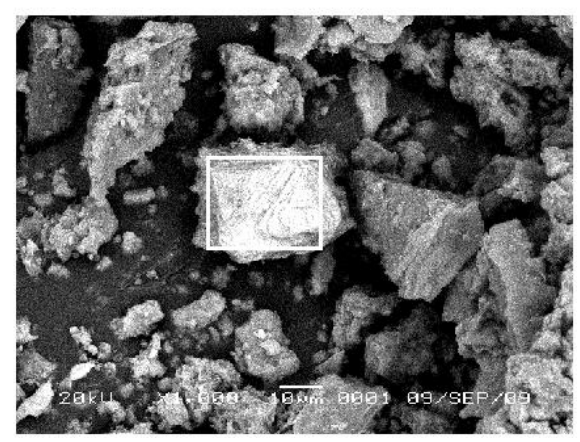

Gambar 7. Hasil SEM-EDX logam berat sampel tanah di Baleendah

Tabel 5. Hasil SEM-EDX logam berat, hasil XRD dan suseptibilitas sampel tanah di Baleendah

\begin{tabular}{llcc}
\hline \multicolumn{2}{c}{ Hasil SEM-EDX } & Hasil XRD & Hasil Suseptibilitas \\
\hline Element & Mass $(\%)$ & Anorthite & Pyrhotite $\left(\mathrm{Fe}_{7} \mathrm{~S}_{8}\right)$ \\
O(oxide) & 30.5 & $(\mathrm{Ca}, \mathrm{Na})\left(\mathrm{Al}, \mathrm{Si}_{2}\right) \mathrm{Si}_{2} \mathrm{O}_{8}$ & \\
Al(alumunium) & 4.59 & $\mathrm{Kaolinite}$ & \\
$\mathrm{Si}($ silika) & 3.88 & $\left(\mathrm{Al}_{2} \mathrm{Si}_{2} \mathrm{O}_{5}(\mathrm{OH})_{4}\right)$ & \\
& & & \\
& & & \\
Ti(titanium) & 11.85 & Quartz & \\
Fe(ferrum) & 49.18 & $\left(\mathrm{SiO}_{2}\right)$ & \\
& & Cristobalite & \\
& & $\left(\mathrm{SiO}_{2}\right)$ & \\
\hline
\end{tabular}

Unsur Fe hasil SEM-EDX sesuai dengan hasil identifikasi mineral berdasarkan nilai suseptibilitas magnetiknya (pyrhotite $\left(\mathrm{Fe}_{7} \mathrm{~S}_{8}\right)$ ), sedangkan adanya unsur $\mathrm{Al}$ sesuai 
dengan hasil XRD yang ditunjukkan dengan adanya mineral anorthite dan kaolinite. Pergeseran perubahan mineral magnetiknya memenuhi formula :

$$
\text { Fe }{ }_{1.759048} \mathrm{Ti}_{0.240952} \mathrm{O}_{3}
$$

Formula tersebut termasuk mineral hematite $\mathrm{Fe}_{2-\mathrm{x}} \mathrm{Ti}_{\mathrm{x}} \mathrm{O}_{3}$ dengan besar $\mathrm{x}$ mendekati nol dan Fe mendekati 2.

Berdasarkan diagram ternary, terlihat pergeseran mineral magnetik dari sampel tanah hutan dan sawah adalah magnetite menuju hematite. Hal ini mengindikasikan bahwa sifat tanah menuju basa karena adanya proses oksidasi, kesuburan tanah sawah menurun dibandingkan dengan sampel tanah dari hutan dilihat dari mineral hasil XRD juga nilai suseptibilitas magnetik.

\section{Struktur Tanah}

Gambar 3.6 di bawah ini merupakan perbesaran sampel tanah sampai ukuran $100 \mu \mathrm{m}, 500 \mu \mathrm{m}$ dan $30 \mu \mathrm{m}$ untuk mengidentifikasi jenis struktur tanah sebagai data pendukung.

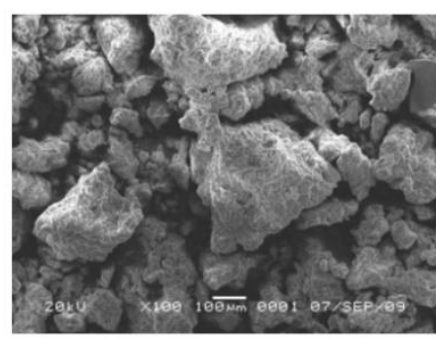

(a)

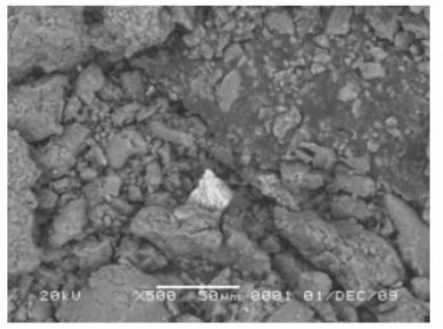

(b)

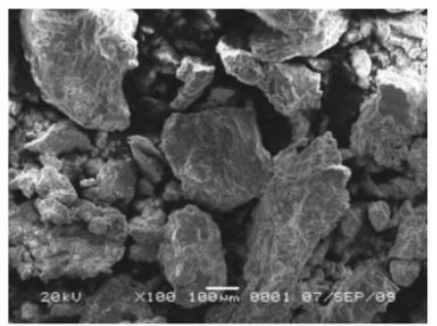

(c)

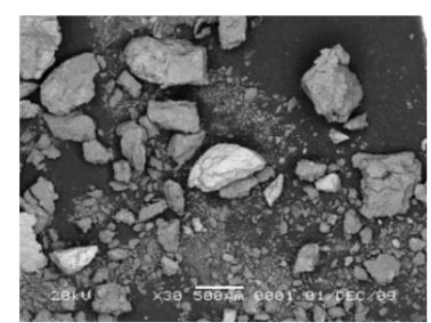

(d)

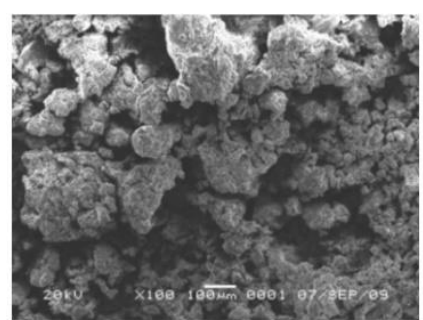

(e)

Gambar 8. Perbesaran sampel tanah hasil SEM-EDX (a) Hutan Djuanda (b) Cisaranten (c) Cigiringsing (d) Sukapura (e) Baleendah

Struktur tanah hutan berupa remah dengan agregat tanah dan porositas masih bersatu, sehingga memperlancar peredaran unsur hara, udara dan air. Struktur tanah dari lahan sawah Cisaranten berupa agregat yang porositasnya besar. Struktur tanah dari lahan sawah Cigiringsing berupa remah hanya saja agregat tanahnya sudah terpisah-pisah dan pori-pori tanah begitu besar. Struktur tanah lahan sawah Sukapura memiliki porositas yang paling besar, karena agregat tanah terpisah-pisah 
begitu jauh, begitu juga dengan tanah dari lahan sawah Baleendah, agregat tanahnya terpisah-pisah dan porositasnya cukup baik.

SEM-EDX dilakukan pada sampel tanah tertentu (yang berasal dari lokasi dan kedalaman tertentu) untuk mengidentifikasi unsur yang terkandung pada tanah sehingga dapat dianalisis unsur yang diduga sisa dari pemupukan.

Tabel 6. Kandungan unsur tanah hasil SEM

\begin{tabular}{lccccc}
\hline & Hutan Djuanda & Cisaranten & Cigiringsing & Sukapura & Baleendah \\
\cline { 2 - 5 } \multicolumn{1}{c}{ element } & Mass $(\%)$ & Mass $(\%)$ & Mass $(\%)$ & Mass $(\%)$ & Mass $(\%)$ \\
\hline C (karbon) & 5.11 & & & 8.83 & \\
O (oxide) & 42.52 & & 44.32 & 42.82 & 19.11 \\
Mg(magnesium) & 1.01 & & 1.59 & 1.17 & \\
Al (alumunium) & 15.68 & 25.39 & 14.09 & 11.97 & 6.92 \\
Si (silika) & 20.69 & 39.66 & 22.26 & 24.72 & 6.57 \\
K (kalium) & 0.42 & & 0.16 & 0.44 & \\
Ca (kalsium) & 0.66 & & 2.47 & 2.2 & \\
Fe (ferrum) & 13.91 & 23.79 & 14.55 & 7.49 & 67.40 \\
Na(natrium) & & & 0.57 & 0.35 & \\
Ti(titanium) & & 11.16 & & & \\
\hline
\end{tabular}

Unsur yang muncul pada sampel tanah sawah adalah $\mathrm{C}, \mathrm{Ca}$ dan $\mathrm{Na}$ dan tidak ada atau jumlahnya lebih besar dibandingkan dengan sampel tanah hutan. Adanya Unsur $\mathrm{C}$, $\mathrm{Na}$ dan $\mathrm{Ca}$ diduga akibat penggunaan pupuk. Pemupukan dapat menyebabkan adanya sisa unsur tertentu dan menyebabkan beberapa kandungan unsur lain menjadi berlebih atau kurang dibanding dengan unsur yang terdapat pada sampel tanah hutan yang dianggap subur dan alami.

\section{Kesimpulan}

Tanah hutan masih subur dan alami karena didominasi mineral magnetik magnetite $\left(\mathrm{Fe}_{3} \mathrm{O}_{4}\right)$, pH netral, konduktivitas cukup besar dan berstruktur remah, sedangkan tanah dari sawah dapat dikatakan sudah terdegradasi karena didominasi mineral magnetik pyrhotite $\left(\mathrm{Fe}_{7} \mathrm{~S}_{8}\right)$ yang berasal dari pemupukan dan titanohaematite $\left(\mathrm{Fe}_{2} \mathrm{O}_{3}-\mathrm{FeTiO}_{3}\right)$ yang menjadikan tanah basa. Selain itu, $\mathrm{pH}$ tanah sawah bersifat netral cenderung basa dan memiliki konduktivitas kecil.

Beberapa unsur yang muncul pada sampel tanah sawah seperti $\mathrm{C}, \mathrm{Ca}$ dan $\mathrm{Na}$ yang tidak ada atau jumlahnya lebih besar dibandingkan dengan tanah hutan. Hal itu diduga akibat penggunaan pupuk yang tidak sesuai kebutuhan yang menyebabkan sisa unsur tertentu dan membuat beberapa kandungan unsur menjadi berlebih atau kurang dibanding kandungan unsur di hutan.

\section{Ucapan terima kasih}

Laboratorium Geofisika UNPAD, Laboratorium Fisika Bumi ITB, Laboratorium Metalurgi Pertambangan ITB, Laboratorium Fisika Batuan PPGL, I-MHERE UNPAD. 


\section{Daftar Pustaka}

1. Dearing and John, Environmental Magnetic Susceptibility Using the Bartington MS2 System. Chi Publishing : England (1999).

2. R. F. Butler, Magnetic Domain to Geologic Terrences : Ferromagnetic Minerals. Blackwell Scientific : USA (1992).

3. R. G. Hardy and M. Tucker, X-Ray Powder Diffraction of Sediments, in Techniques in Sedimentology . Blackwell : London (1989).

4. Sarief, Saifudin, Ilmu Tanah Pertanian . Pustaka Buana : Bandung (1992).

5. Shancez, A. Pedro, Sifat dan Pengelolaan Tanah Tropika . ITB : Bandung (1992).

6. A. D. Suyono dkk, Kesuburan Tanah dan Pemupukan. RR Print : Bandung (2006). 